\title{
SOCIALINĖS SĄVEIKOS TARP JUDE்JIMO NEGALIĄ TURINČIŲ IR NETURINČIŲ VISUOMENĖS NARIŲ YPATUMAI
}

\section{JOLITA VILUCKIENE் KLAIPÉDOS UNIVERSITETAS}

Šiame straipsnyje, pasitelkiant Alfredo Schützo sociologini fenomenologinị žvilgsni ir asmenines judejjimo negalia turinčiu žmoniu naracijas, atskleidžiama, kaip vežimèliu judantys asmenys išgyvena ir patys interpretuoja probleminius santykius su igaliais visuomenés nariais. Pagrindinis veiksnys, salygojantis tarp ju egzistuojančia intersubjektyvaus supratimo stoka ir komunikacinius nesklandumus, yra skirtingos natūralaus pasaulio vaizdo ir interpretaciju sistemos, kuriomis vadovaujasi šiu grupiu nariai.

\section{IVADAS}

Nuo seno žmonės neiggaliais buvo laikomi ne dèl savo poreikių išskirtinumo ar negalios dydžio, bet dèl silpnumo. Daugiausia dèmesio buvo kreipiama i jų išskirtines savybes ir pabrèžiama, kuo jie skiriasi nuo kitų, bet nežiūrima, ką turi bendra su kitais žmonėmis (Gudonis, Novogrodskienė, 2000). Toks požiūris ị neigaliuosius yra išlikęs ir mūsų dienomis. Judejjimo negalią turintys asmenys išsiskiria savo išorinėmis savybėmis, neatitinkančiomis "normalaus“, arba „,standartinio“, žmogaus ivvaizdžio, todèl jie tampa ypač savita visuomenès grupe, kurią likusieji visuomenès nariai dažniausiai suvokia ir vertina kaip priklausančius „jie“ grupei, t. y. kitokių, svetimų, nepažistamų ir vengtinų žmonių grupei. Tai atsitinka būtent dèl kitokios, „nenormalios“ kūno išvaizdos 
ir sėdèjimo neigaliojo vežimėlyje. Tarp šių žmonių ir kitų visuomenės narių egzistuojantis socialinis nuotolis trukdo neigaliuju integracijos procesui. Ši socialini nuotoli gilina tai, jog dauguma visuomenès žinių apie neigaliuosius yra gauta ne iš ju pačiu, o tèra visuomenès nuomonè apie juos (Šeporaitytė, Tereškinas, 2007: 20). Ta nuomonè apipinta gausybės neigiamų nuostatų neigaliųjų atžvilgiu, o tai apsunkina socialinę sąveiką tarp negalią turinčių ir jos neturinčių visuomenès narių ir trukdo jiems sẻkmingiau îsilieti ị socialinị, kultūrinị, politinį bei ekonominị visuomenès gyvenimą ir tapti visaverte jos dalimi.Todèl labai svarbu išgirsti ir įsiklausyti, ką patys neigalieji kalba apie save ir savo santyki su negalios neturinčiais žmonemis.

Pozityvistine paradigma pagrịsti tyrimai nèra pajègūs atskleisti subjektyvios negalios tikrovės, kuri išreiškiama vidinėmis toje tikrovejje veikiančių subjektų reflektuojamomis patirtimis. Todèl šiame tyrime pasitelkiama Alfredo Schützo fenomenologinè sociologijos metodologija, kuri leidžia tirti subjektyviai reikšmingą gyvenimo su negalia patirti, nes ji remiasi ne pozityvistine epistemologija, pagrịsta objektyviu, išoriniu empirinès tikrovès pažinimu, bet konstrukcionistine, kuri pabrèžia tiriamų subjektų suvokima, jų socialinio konteksto svarbą bei priima individus kaip aktyvius prasmės kūrëjus, o ne išoriškai ir objektyviai apibrèžtų reikšmių gavejjus (Natanson, 1970: 15).

Kadangi visuomeneje egzistuoja daugybè žmonių, kurie patys neturi negalios, niekada nebuvo iš arti susidūrę su šiuo reiškiniu arba savo žinojimo atsargose turi gana miglotą šio reiškinio ir vežimèliu judančių žmoniu gyvenimo vaizda, A. Schützo terminais kalbant, pastaruosius galima îvardyti kaip atskirą kategoriją ar socialinį žmonių tipa, apie kuri „sveikieji“ visuomenès nariai kaip svetimieji, t. y. nepriklausantys šiai tiriamai grupei, turi susidarę išorini „objektyvu“" vaizdą. Tačiau ši objektyvia "sveikujų laikoma interpretacija apie judejimo negalią turinčių asmenų grupę yra, anot A. Schützo, tik abstraktus jos konstruktas. Pasinaudodami savo tipizacijų ir aktualių reikšmių sistema, jie susumuoja grupès narių tam tikras pastebėtas charakteristikas ir bruožus i vieną socialinę kategorija, kuri jiems atrodo homogeniška ir objektyvi (Schutz, 1970: 94). Bet tai yra tik išorinė interpretacija, kuri paprastai neatitinka tiriamos grupès narių, šiuo atveju judejjimo negalią turinčių žmonių vidinės interpretacijos. A. Schützo fenomenologinès sociologijos įžvalgos puikiai padeda suprasti ir moksliškai analizuoti judejjimo negalią 
turinčių asmenų socialini pasauli, atsigręžiant i pačius socialinius veikejjus, kuriems šis pasaulis egzistuoja ir kuriame jie yra veikiantys bei patiriantys subjektai, susisaistę vieni su kitais ịvairiausiais socialiniais ryšiais ir tiems ryšiams bei visai patiriamai tikrovei priskiriantys savitas, subjektyvias prasmes (Schutz, 1967: 10).

Tokia epistemologine prieiga atskleista neigaliojo vėžimėliu judančio žmogaus intersubjektyviai išgyventa socialinė sąveika su kitais visuomenės nariais aktuali, norint keisti visuomeneje vyraujantị išorinị "objektyvų", bet dažnai tikrovės neatitinkantị šių žmonių gyvenimo vaizda, kuris tik komplikuoja santyki su jais. Socialiniams darbuotojams bei sveikatos priežiūros specialistams, teikiantiems judejjimo negalią turintiems asmenims socialines ir medicinines paslaugas, taip pat svarbu praplèsti savo žinių bagažą.

Tad šio straipsnio tikslas - pasitelkiant Alfredo Schützo sociologinį fenomenologinị žvilgsnị ir asmenines judèjimo negalią turinčių žmonių naracijas, surinktas kokybinio giluminio interviu metu ${ }^{1}$, atskleisti, kaip vežimėliu judantys asmenys jaučiasi ,igalioje“ visuomenèje, kaip jie interpretuoja savo santykị su negalios neturinčiais visuomenės nariais ir iš savo perspektyvos suvokia įvairias išgyventas situacijas socialinių sąveikų metu.

Straipsnyje pirmiausia pristatomas A. Schützo izžvalgomis paremtas skirtingų visuomenès narių susiskirstymas i "mes" ir "jie“ grupes bei atitinkamų santykių tarp šių grupių formavimasis. Šiuo susiskirstymu pažymėta neigaliųjų socialinė sąveika su negalios neturinčiais žmonėmis. Kitame poskyryje atskleidžiamas vežimèliu judančių asmenų ivairiose socialinėse situacijose patiriamas žemesnio, stigmatizuojančio socialinio statuso primetimas iš igalių visuomenès narių pusės. Paskutiniame poskyryje analizuojama intersubjektyvaus supratimo stoka, su kuria susiduria neigalieji ne tik atsitiktiniu, bet ir institucionalizuotu sąveikų su sveikatos ar socialinės priežiūros specialistais metu.

\footnotetext{
${ }^{1}$ Straipsnis parengtas J. Viluckienès (2011) disertacijos „Judejjimo negalią turinčiu asmenų fenomenologinè gyvenamojo pasaulio analizè " empirinio tyrimo pagrindu. Kokybinis tyrimas buvo atliktas Lietuvos paraplegikų asociacijos stovyklavietejje Monciškèse (Palangos m. sav.) 2008 m. liepos - rugpjūčio ménesiais. Apklausti 60 neigaliojo vežimèliu judantys 22-55 metų amžiaus vyrai (31) ir moterys (29), turintys nuo dviejų ir daugiau metų gyvenimo turint negalią patirti. Iš jų: 48 - neigaliais tapę po stuburo traumos ar ligos, 12 - su negalia nuo vaikystès.
} 


\section{"MES"IR „JIE" GRUPIŲ NARIŲ SANTYKIŲ DICHOTOMIJA}

Kaip jau straipsnio pradžioje minėta, iš visuomenėje vyraujančių nuostatų neigaliųjų atžvilgiu bei tam tikrų socialinės sąveikos nesklandumų galima įžvelgti tarp „sveikų“ ir neiggalių visuomenès narių egzistuojantị simbolini susiskirstymą i "mes" ir ,jie" grupes. Toki susiskirstymą ir atokią „sveikujų " laikyseną neigaliųjų atžvilgiu galima paaiškinti A. Schützo ịžvalgomis apie gyvenamojo pasaulio veikèjo natūralios nuostatos mąstymą ir reliatyviai natūralaus pasaulio vaizdo susidary-

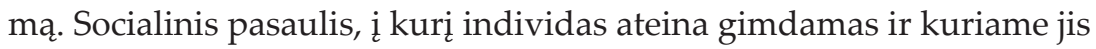
save aptinka, rašo A. Schützas, yra patiriamas kaip glaudžiai supintas socialinių santykių, ženklų ir simbolių su tam tikra jų prasmių struktūra, institucionalizuotų socialinės organizacijos formų, socialinių statusų sistemos ir panašių dalykų tinklas (Schutz, 1970: 79). Tai, kokị vaizdą apie ši pasauli individas susidarys ir kokias jam reikšmes priskirs, priklauso nuo socialinės grupès ar bendruomenės, kurioje individas užauga ir socializuojasi.

Šiai grupei (ir ne tik jai) įvardyti A. Schützas pasitelkia Williamo Grahamo Sumnerio terminą in-group, kuriam galima pritaikyti mes-grupe atitikmenį. Jos nariams būdingas bendras reliatyviai natūralus pasaulio vaizdas, kuri pasitelkus visų šių socialinio pasaulio elementų reikšmès mes-grupés nariams yra savaime suprantamos, nekvestionuojamai perimamos ir objektyvizuotos kaip tipizaciju apie gyvenamajj pasauli sistema (Schutz, 1970: 80). Individai, veikdami gyvenamajame pasaulyje, visada yra vienuc ar kitų socialinių grupių, bendrijų nariai, todèl nepriklausantys mes-grupei asmenys laikomi kitos, jie-grupés (out-group) nariais. Tai yra išorinė grupè, ir jos nariams mes-grupés gyvenimo ir mąstymo būdas nèra akivaizdi tiesa, todèl abieju grupių nariai vieni kitus laiko prašalaičiais ir svetimais (Schutz, 1970: 85). Negalios neturintys visuomenès nariai, socialiai sąveikaudami su neigaliaisiais, dažnai savo laikysena demonstruoja, kad neigalieji yra jie-grupés atstovai, nes tiesiog labai mažai apie juos žino, o turimos žinios dažniausiai neatitinka tikrovès, kurioje gyvena žmonès su judejjimo negalia. Dauguma tyrimo metu kalbintų informantų dalijasi šios dialektinės socialinės sąveikos su „sveikaisiais" patirtimi: 
Tarkim, taip, žmoniu maždaug yra tokia reakcija: gerai, bendraujam, kalbam, viskas normaliai, o kai artimiau reikia pradèt bendraut, atstumia arba pradeda gaileti: "Vai kaip tau sunku“. Ir panašiai. (Lukas, 23 m., su negalia $9 \mathrm{~m}$.

Dèl bendravimo galiu pasakyti vienareikšmiškai: pas mus žmonės nemoka bendrauti su neigaliaisiais, sakysim, dauguma. <..> Pirma reakcija-baimé: "Velnias, ko jis nori iš manęs?" Kol tavęs nepažista ir nežino, ko tu asmeniškai noresi. Kai pamato, kad nekeli jam jokiu problemu, tai tas bendravimas tampa labai normalus, viskas büna gerai. (Titas, 35 m., su negalia 9 m.)

A. Schützas, nagrinėdamas išorines ir vidines skirtingų grupių narių laikysenu perspektyvas, teigia, jog prašalaitis, t. y. kitos grupės narys, yra vertinamas ir nagrinëjamas pagal mes-grupejje vyraujančius standartus ir natūralaus pasaulio vaizdo reikšminę sistemą. Jeigu nerandama transformacijos formulè, kuri leistų jie-grupejje vyraujančią aktualių reikšmių ir tipizacijų sistemą perprasti ir paversti sava tipizacijų sistema, kuria vadovaujamasi mes-grupejje, tai pirmosios grupės narių gyvenimo ir veiklos būdai lieka nesuprantami ir dèl to yra menkinami palyginti su savaisiais (Schutz, 1970: 85). Ši A. Schützo įžvalga atskleidžia, kodèl atsiranda socialine ittampa tarp neigaliu ir negalios neturinčių visuomenės narių. Pagrindinis veiksnys, sąlygojantis šių visuomenės grupių tarpusavio intersubjektyvaus supratimo stoką ir komunikacinius nesklandumus, yra skirtingos natūralaus pasaulio vaizdo ir interpretaciju sistemos. Tiksliau sakant, neigalieji dažnai jaučiasi nesuprasti „sveikųjų“, kaip jie-grupés narių. Tai kyla iš priešiškų išankstinių nuostatų ar blogų i̇sitikinimų, kuriuos išorinės grupės nariai, šiuo atveju negalios neturintys žmonès, laiko savaime suprantamomis ir akivaizdžiomis tiesomis (Schutz, 1970: 86). Tai paliudija aukščiau pateikti respondentų Luko ir Tito pasidalijimai patirtimi, iš kurių matyti, kad neigalieji vis dar susiduria su visuomenèje vyraujančiais stereotipais, kuriais sąveikų metu vadovaujasi negalios neturintys žmonės. J. Ruškaus (1999) pateiktame socialinių nuostatų neigaliųjų atžvilgiu struktūriniame-teoriniame modelyje viena iš vyraujančių nuostatų yra artimumo atmetimas, t. y. dažni atvejai, kada negalios neturintys asmenys atsisako asmeninių santykių su neigaliuoju. Galima sakyti, tai sąlygoja neadekvatus ir perdèm siauras daugelio visuomenės narių žinojimo apie neigaliuosius bagažas. Todèl nenuostabu, kad, bendraujant 
su neigaliuoju, „sveikiesiems“ kyla baimė, vidinè ittampa, netikrumas, jie nežino, kaip elgtis. Būtent šiomis patirtimis dalijosi aukščiau minèti informantai.

Tačiau bene pirmoji ir labiausiai paplitusi vežimèliu judančio neigalaus asmens patirtis, kurios metu jis pajunta esąs priskiriamas jie-grupei, - tai ¡kyrus gatvès praeiviu žiūrèjimas, atokus tyrinèjimas žvilgsniu, kuris demonstruoja jų išankstinį neiggalaus asmens kaip svetimo, priklausančio kitam, nepažistamam pasauliui, kategorizavimą. İkyrų praeivių žiūrèjimą neigalieji vertina skirtingai, tai priklauso nuo to, kiek metu judama vežimėliu, ir nuo negalios kaip savo asmenybès dalies integravimo arba atmetimo. Paprastai ilgainiui dauguma neigaliųju apsipranta su šia patirtimi ir beveik nebekreipia į tai demesio, tačiau asmenys, kurie nesusitaikè su negalia ir jaučia dèl jos nevisavertiškumo kompleksą, praeivių žvilgsnius priima itin jautriai ir dèl to vengia viešųjų erdvių. Algis ir Renata dalijasi neigiamais išgyvenimais dèl minèto aplinkinių žiūrëjimo:

Yra kartais toks kažkoks kompleksas, kai varsto tave žvilgsniais, tai nelabai patinka. <...> Kažkaip tai nejaukiai, nežinau net dèl ko, vis tiek visu žvilgsniai ir žmonès kažkaip keistai žiūri. (Algis, 35 m., su negalia 9 m.)

Ir jau stengiuos vengt. Neinu aš va, pavyzdžiui, anksčiau labai va mégdavau eit po parduotuves, ten, o dabar aš kaip tik ju nemégstu, aš ten visa laika važiuoju su mašina ir sesés prašau: "Eik tu man nupirk maisto, nes aš nenoriu. (Renata, $32 \mathrm{~m}$. , su negalia $8 \mathrm{~m}$.)

Lina ir Modesta, priešingai, pasakoja, kaip tie skausmingi nužiūrinèjimo išgyvenimai jau seniai yra nusèdę i patirčių bagažą ir nebejaudina, kaip negalios igijimo pradžioje, nes jos nèra internalizavusios savo negalios kaip stigmatizuojančios ju socialinę tapatybę ir/arba sėkmingai praejjusios identiteto transformacijos etapą po biografinio lūžio, ìvykusio dèl stuburo traumos:

Dabar tai aš jau ju nebematau praktiškai. Sakykim, ten važiuojant gatve, aš turiu jau tada isijausti, kad pastebéčiau, kad žmonés i mane žiūri. Na, ir jei man užplaukia, tada aš irgi pradedu bjauriai elgtis, pradedu irgi žiūrèti, žinai, <...> man tada jau būna tai žaidimo forma, pasilinksminimas. (Lina, $32 \mathrm{~m}$. , su negalia $18 \mathrm{~m}$.)

Man, kaip sakoma, dzin. Na, tikrai, važiuoji, važiuoji, kas žiūri, tegu žiūri. <...> Kartais ikkyri, lyg ir pykina, bet vis pagalvoju: galbūt ir aš, jeigu büčiau nesusidūrusi su tuo, nes iki ligos nesusidūriau, tikrai, gal irgi žiūréčiau, gal irgi atsisukčiau, gal irgi būtu keista. (Modesta, 41 m., su negalia $23 \mathrm{~m}$. ) 
İkyrūs praeivių žvilgsniai yra tik vienas iš požymių, rodančių egzistuojantị socialinį nuotolị tarp neigalių ir igalių visuomenės narių. Toliau analizuojami išgyvenimai, kuriuos patiria neigalūs asmenys tiek atsitiktinių socialinių sąveikų su gatvės praeiviais metu, tiek kontaktuodami su socialiniais darbuotojais ar kitais socialinès srities bei sveikatos priežiūros specialistais. Ši reflektuota patirtis padeda atskleisti igaliu visuomenės narių nelygiaverčių, stigmatizuojančių socialinių santykių primetimą neigaliesiems.

\section{VEŽIMÉLYJE SĖDINČIO ASMENS TIPIZAVIMAS, PRISKIRIANT JI ŽEMESNIAM, STIGMATIZUOTAM SOCIALINIAM STATUSUI}

Siekdamas paaiškinti, kaip socialiniame pasaulyje žmonès, tik iš dalies arba visai nepažindami vieni kitu, tarpusavyje komunikuoja ar tiesiog stebi savo bendraamžininkus, t. y. esančius vienu metu bendroje socialinèje erdvëje, A. Schützas pasitelkia interpretacinę idealiųjų tipų schemą (Schutz, 1967: 186). Ją konstruodamas, jis perima ir savaip panaudoja Weberio „idealiojo tipo“ sąvoka, išskirdamas du šio idealiojo tipo pobūdžius ir pavadindamas juos "personaliniu“ ir „veiksmo eigos" idealiaisiais tipais (personalandcourse-of-actionidealtype). Pirmu atveju tai yra kito asmens, kuris išreiškia save tam tikru būdu, idealusis tipas, antru atveju - tai paties išraiškos proceso arba jo regimo rezultato idealusis tipas. Be abejonės, abu juos sieja vidinis ryšys, nes, kaip aiškina A. Schützas, aš negaliu apibrèžti pašto darbuotojo idealaus tipo, nepažindamas jo atliekamo darbo. Bet, jei aiškiai apibrèžiu veiksmo eigos tipa, tai pagal ji galiu konstruoti atitinkamą personalinį idealujji tipa, t. y. asmeni, kuris atlieka šią veiklą (Schutz, 1967: 187). Šiems idealiesiems tipams būdingas objektyvus prasmės kontekstas, nes jie yra socialiai perimami ir kartu su subjektyvios patirties klodais nugula i parankinio žinojimo atsarga, naudojamą suvokti ir interpretuoti patiriamą socialinę tikrovę. Žvelgiant iš subjektyvios prasmès interpretacijos perspektyvos, socialinis pasaulis yra konstituojamas būtent pagal šiuos personalinị ir veiksmo eigos idealiuosius tipus, tiek santykiuose su daugiau ar mažiau pažistamais žmonèmis, tiek su visiškais anonimais (Natanson, 1970: 111). Taigi tipizuoti individai, kuriems yra priskiriamas tam tikras tipiškas socialinis vaidmuo ar funkcija, socialiniame horizonte figūruoja iš esmès tik per jiems priskiriamo tipizuoto vaidmens prizmę (Gurwitch, 1975: XXV). 
Šis A. Schützo interpretacinės idealiųjų tipų schemos, taikomos bendraamžininkui atpažinti netiesioginio kontakto metu, išdèstymas paaiškina, kodèl nuo vaikystès ir po stuburo traumos ị vežimèli atsisẻdę asmenys išgyvena visuomenès jiems primetamą neigaliojo socialinị statusa, kuris turi ganėtinai neigiamą konotaciją, ataidinčią iš Talcotto Parsonso (1951) apibrěžto sergančiojo vaidmens. Tik šiuo atveju neigalusis yra permanentiškai „sergantis“, todèl našumo ir produktyvumo prasme nenaudingas visuomenės narys. Tokius sutiktus žmones ,igalieji“ paprastai kategorizuoja, priskirdami juos, A. Schützo terminais, negatyviai stereotipizuotam neigaliojo personaliniam idealiajam tipui.Tad nenuostabu, kad socialinių sąveikų metu vis dar pasireiškia vežimèlyje sẻdinčio asmens žeminimo atvejų, kokius ne kartą yra patyrusi informantė Irena:

Kartais vat būna tokiu grubiu, kažkokiu išsireiškimu, kada tas sveikas tave nori nužeminti. Va taip būna, pavyzdžiui, jau tu esi čia tokia, tai reiškia, tu čia turi büti žemiau, žemiau... Bet reikia pačiam žinoti, kodèl ten mane turi vien dèl to žeminti, kad aš nesveika? (Irena, 52 m., su negalia $42 \mathrm{~m}$.)

V. Gudonis ir E. Novogrodskienè (2000), pasiremdami dar prieš tris dešimtmečius išsakytomis Šulteiso (1975) ižzalgomis, pabrěžia, jog neigaliųjų adaptacijai didžiausių kliūčių kyla ne dẻl kasdienių sunkumų, susijusių su negalia, bet dèl visuomenès nepakankamos pagarbos, neigaliųjų asmenybės menkinimo bei netinkamo požiūrio ị juos (p. 51). Tačiau tie neigalūs asmenys, kurie yra įsisąmoninę ši jiems primetamą antrarūšio piliečio statusa, priešinasi tokiai stigmatizacijai ir siekia įvairiais būdais įtvirtinti pozityvia, lygiavertę kitiems visuomenès nariams socialinę tapatybę. Pavyzdžiui, informantė Lidija viso pokalbio metu ne vieną syki pabrèžė jai ypač reikšmingą nuostatą apie save kaip neigalų žmogu, vartodama normalumo kategorija, nes ji itin aiškiai suvokè, kaip ją aplinkiniai nori issprausti i žemesni socialinị statusą vien dẻl to, kad po stuburo traumos nebegalėdama vaikščioti ji sẻdo ị vežimèli:

Mes tokie patys žmonès, tiktai kitas kūnas, kad mes negalim vaikščioti. Paprasčiausiai mes nevaikštom, o vežimèly važinejjam tik. Čia nèra žemesnis lygis, tiktai kad mūsu ne tiek daug mieste pamatysi, nes néra salygu. Mes normalūs žmonès, tiktai fiziškai mes negalim paeiti. Ne visi tai supranta. Aš nežinau, kažkaip tai neskaitau save neigalia, invalide, negaliuke. (Lidija, $27 \mathrm{~m}$. , su negalia $2 \mathrm{~m}$.) 
Nuo vaikystės vežimèliu judanti Roberta pastebi, jog kitiems žmonėms tenka aiškinti ir įrodinèti, kad neiggalieji gali gyventi visaverti gyvenimą ir užsiimti tokiomis pačiomis socialinėmis praktikomis kaip ir kiti visuomenės nariai, todèl ji, kalbėdama apie neigaliųjų socialini statusa, dažnai kartoja posakius ,"kaip ir visi“, ,"tokie pat" , "taip pat":

Mes esam tokie pat žmonès, taip pat dirbam, taip pat kuriam šeimas, darom viska taip pat, kaip ir kiti. Man, pavyzdžiui, büna keista, kai nustembama, kad neigalusis turi šeima, vaiku. Kaip tai? Bet tai yra normalu: neigalusis taip pat turi teise ir gali turèti šeima, vaiku. (Roberta, 25 m., su negalia $25 \mathrm{~m}$.)

Be to, ši mergina atkreipè dèmesị ir ị tai, kad socialinès sąveikos su aplinkiniais metu neigaliam asmeniui neretai yra primenamas jo neigalumas, ypač kai jis sėdi neiggaliojo vežimèlyje, nes pirmiausia išskiriama ši jo socialinė kategorija. Tai patvirtina galbūt gerai neįsisąmonintą negalios neturinčių visuomenės narių socialinę kategorizaciją ir tipizaciją $i$ „,sveikuosius" ir neigaliuosius:

Pavyzdžiui, stovi parduotuvejje dvi moterys: viena sveika, kita neigalioji. Pastebi, kad va čia stovi žmogus, o ten - neigalusis. Pirmiausia pastebi neigaliojo neigaluma, o tik véliau lyti, kad čia konkrečiai yra moteris. Arba sako: "Praleiskit neigalia moteri", bet nesako: "Praleiskit moterį"; vis tiek pabrěžia [neigaluma]. (Roberta, 25 m., su negalia $25 \mathrm{~m}$.)

Esant tokiai socialinei atmosferai, nenuostabu, jog normalizacijos reiškinys, t. y. pastangos siekti tokio gyvenimo būdo, kuris būdingas didžiajai visuomenès daliai, taip stengiantis neišsiskirti iš kitų ir turèti realų pagrindą atmesti antrarūšio piliečio statusa, dažnai būdingos daugeliui judejjimo negalią vẻlesniame gyvenimo tarpsnyje patyrusių žmonių, ypač tų, kurie po traumos išliko arba susigrąžino gana aukštą savarankiškumo lygị, leidžiantị visu pajègumu užsiimti darbine, profesine ir kita veikla. Tai patvirtina ir Mariaus Daugèlos (2006) kokybinio tyrimo rezultatai, - jis pastebi, jog neigalieji nori prilygti ar bent jau nenusileisti "sveikiesiems“ visuomenés nariams (p. 12). Toki troškimą normalizuotis geriausiai iliustruoja informantès Sigitos mintys:

Žinai, kai tu jau dabar va persilaužei per ta negalia ir tu GALI, tai tada nori, atrodo, kaip ir visi. Aš savęs nelaikau, kad esu kitokia, bet aš stengiuosi ir nebūti kitokia. Žinai, noriu büti kaip visi. Ir aš noriu gyventi pilnaverti gyvenima, ir todèl aš siekiu, kaip visi kad siekia. (Sigita, 27 m., su negalia $8 \mathrm{~m}$. 
Šie normalizuotis siekiantys neigalūs asmenys daug dėmesio skiria ir savo išvaizdai, kratydamiesi tipizuoto vaizdinio, kad neigalusis yra vargšas, skurstantysis, panašus ị išmaldos prašantị žmogų:

Sakykim, būti kažkaip apsileidusiam, ta prasme, kad jau ten nesusišukavusiam, nesidažyti plauku ar dar kažko tai, tai man tokie dalykai nesuprantami; vien dèl to, kad aš vežime sèdžiu, kodèl aš dabar turiu būti kitokia negu "sveikieji“? (Irena, 52 m., su negalia $42 \mathrm{~m}$.)

Būdami socialiai aktyvūs, jie patiria, kad yra kitų matomi. A. Schützas šitaip aiškina buvimą Kito akivaizdoje: „Kai Kitas žvelgia i̇ mane, manyje vyksta esminis pokytis: aš tampu sąmoningas savo paties atžvilgiu, t. y. save suvokiu kaip objekta, esanti Kito apibrėžtoje situacijoje. <...> Aš jau nesu vien sau pačiam, bet ir Kitam, nes atsiranda Kitas, kuris apibrėžia mane ir mano situaciją šiame pasaulyje iš savo požiūrio taško" (Schutz, 1962: 189). Tad asmenys, kuriems svarbus ne tik savo pačių, bet apskritai neigalaus asmens įvaizdis visuomenės akyse, reikšmingu dalyku laiko kūno estetika, nuo kurios priklauso tiek vidinė asmens laikysena (nes „Kito akivaizdoje išgyvenu gėdą arba pasididžiavimą" (Schutz, 1962: 189), tiek sẻkminga socialinè sąveika su kitais:

Man pavyko kaip i̇manoma maksimaliai išlikti švariam visu pirma, pasitempusiam, gražiam. <...> Aš manau, kad tai duoda galimybe gerai jaustis. (Minvydas, $32 \mathrm{~m}$. , su negalia $12 \mathrm{~m}$.)

D.: Kaip čia va kartais matau, yra kai kurie žmonès [rateliuose], galètu ir apsirengti kažkaip gražiau, normaliau, ne vien su tom treninginèm susuktom kelnem ar ten kažkokiom kojinèm.

T.: Tai tu manai, kad vis tiek neigalus žmogus, sédintis vežimélyje, turi atrodyti nepriekaištingai?

D.: Taip, bütinai. Ir ne kitaip. Turi atrodyt jisai gerai, tvarkingai. (Donata, $27 \mathrm{~m}$. , su negalia $8 \mathrm{~m}$.)

Kita dalis neigaliujų siekia visiškai atmesti ši naują su negalia igytą statusą. Po stuburo traumos atsisèdę i̇ neigaliojo vežimèlį, jie stengiasi išlaikyti savo ankstesnị socialinị status quo, atsiriboti nuo kitų neigaliujuu, siekdami patys "pamiršti“ savo neiggaluma, nesitapatinti su jais ir bendrauti daugiausia su savo artimaisiais ir draugais, kurie neprimena ju negalios ir yra išlaikę iprastus, prieš traumą nusistovėjusius bendravimo santykius. Tokią laikyseną iliustruoja informantų Minvydo ir Igno pokalbiuc ištraukos: 
Draugai šalia, šeima šalia. <..> Ir kai aš vienas su jais, tai taip pat jaučiuosi. Ypač kai už stalo sèdi, tai išvis nesimato [negalios]. <...> Na, va, gal dèl to aš mažai bendrauju [su neigaliaisiais], nes tada aš suprantu, koks aš esu. (Minvydas, 32 m., su negalia $12 \mathrm{~m}$.)

Aš čia šiaip prie invalidu va pirmakart gyvenime, va tokiam sambūry esu atvažiavęs. <...> Nedalyvauju tarp tokiu. <...> [Bendrumas tarp mūsu] na, gal tik tiek, kad sédim, o taip tai nežinau, nemanau, kad būtu. (Ignas, 24 m., su negalia $14 \mathrm{~m}$.)

Žinoma, visada esti žmonių, savo negalią išgyvenančių kaip stigmą, "sugadinusią" jų socialinę tapatybę, jie yra internalizavę jiems „sveikujjü" itteigtą menkinančios konotacijos neigaliojo tipa, todèl patiria nevisavertiškumo ir kitus negatyvius jausmus. Tokie neigalūs asmenys, kaip pastebi M. Daugèla (2006), yra pasidavę negaliai, pralaimėję kovą su ja, nededa jokių pastangų ką nors pakeisti (p. 12). Todėl jie yra ypač neigiamai vertinami pačių neigaliujjų, kurie nesitapatina su aukos vaidmeniu, bet siekia sau ir kitiems visuomenès nariams irodyti, kad negalia neatima iš žmogaus teisès ir galimybės siekti užsibrèžtų tikslų ir gyventi ne vien tik iš socialinès paramos:

Nereikia zysti: "aš to negaliu", "man tai nepritaikyta", "aš to nepadarysiu“, "man ten to neduoda". Ka žmogus nori padaryti gyvenime, ta tu pasieksi. (Akvilè, $28 \mathrm{~m}$. , su negalia $11 \mathrm{~m}$.)

Čia tu pats suvoki, kad pats esi už savo gyvenima atsakingas. <...> Tai čia tie ratai iš tikruju yra lengviausias pasiteisinimas: "Oi, va, matai, aš sèdžiu, aš negaliu." Bet iš tikruju tai dar daugiau galimybiu yra. <...> Kiek tu įdesi pastangu, kiek tu iddesi savo energijos, tiek jëgu ir bus, ta ir turési. (Raimonda, $34 \mathrm{~m}$. su negalia $17 \mathrm{~m}$.)

Dalis neigaliựu, susitapatinusių su antrarūšio piliečio statusu, gyvenimo nuskriaustojo, aukos vaidmeniu, neretai siekia pasinaudoti šiuo savo statusu ir i̇vairiausiose srityse nuolat reikalauja socialinès malonès iš visuomenès vien todèl, kad yra neigalūs. Informantẻ Justina pati prisipažista, kad naudojasi savo padètimi:

$\mathrm{Na}$, tiesiog vat šioj srity tai yra privalumas, tu gali gauti viska, turédamas ta negalia, kaip sakant, vis tiek žmonès pažiūri, nu gailestis yra tas, vat ir gali pralįsti. <...> Būna, kad žmonès žiūri labai taip, tada sakau: "Nežiūrèk geriau, o duok pinigu“. (Justina, $25 \mathrm{~m}$., su negalia $7 \mathrm{~m}$.)

Tokia jų laikysena prisideda prie to, kad visuomenèje nemažeja neigiamų nuostatų neigaliưjų atžvilgiu, taip pat juos neigiamai vertina ir kiti 
negalią turintys asmenys, kurie nesinaudoja savo neigalumu ir nori būti laikomi lygiaverčiais visuomenès nariais:

Ir iš viso negalia ir visa, kas susije su negalia, tai toks ivaizdis ir yra: tokio vargšo, nuskriausto. Tai iš tikruju per ivaizdi labai kerta tokie dalykai. Tas atejo iš to, kad atsiranda tokiu pavieniu, kurie ir sveiki būdami kažkaip tai stengiasi suktis, ant kito sprando gyvent, o čia susidaro idealios salygos. (Titas, $35 \mathrm{~m}$. , su negalia $9 \mathrm{~m}$.)

Taigi, kaip matyti, kiti visuomenės nariai kategorizuoja judejjimo negalią turinčius asmenis, tipizuodami juos kaip antrarūšius piliečius, žemesnès vertės, neproduktyvius, permanentinio sergančiojo vaidmeni atliekančius ir dèl to gailesčio vertus visuomenès narius. Siekdami išvengti negatyvaus poveikio jų socialinei tapatybei, vieni asmenys siekia normalizuotis, t. y. savo gyvenimo būdu neišsiskirti iš kitų visuomenės narių, kiti - vengti neigaliuju, visiškai nesitapatinti su jais ir ignoruoti ši statusa, dar kiti - ieškoti pozityvių moralinių neigalumo aspektų. Tačiau visada esti dalis neigaliụjų, kurie jaučiasi stigmatizuojami, tačiau kartu naudojasi savo socialine padètimi, tapatindamiesi su socialiai nuskriaustujų vaidmeniu, laukdami ar net reikalaudami ịvairių lengvatų ir socialinès paramos iš visuomenès. Tokiu būdu jie tik patvirtina ir palaiko apie save egzistuojančias socialines stereotipines nuostatas, kurias visuomenès nariai linkę taikyti visiems judejjimo negalią turintiems asmenims.

\section{INTERSUBJEKTYVAUS SUPRATIMO TARP IGALIŲJU IR NEIGALIUJUU PROBLEMA}

2003 m. visuomenès nuomonès ir rinkos tyrimų centras "Vilmorus" atliko sociologinị tyrima, kuriuo siekè išnagrinèti, kaip Lietuvos gyventojai vertina neigaliujjų padètị ir jų teisių apsaugos efektyvumą šalyje. Iš tyrimo duomenų matyti, jog neigalieji patiria socialinę izoliaciją nes ju nepažista net 57,4 proc. jaunimo ir 44,7 proc. vyriausios amžiaus grupés respondentų (Dobryninas ir Gaidys, 2003). Todèl visuomenèje vis dar dažnas požiūris ì neigalųji kaip ì žmogų, apie kurị nieko nežinoma. Dèl informacijos stokos arba abejingumo neigaliu žmogumi visiškai nesidomima, dažniausiai tol, kol negalia nepaliečia asmeniškai arba kol netenka tam tikromis aplinkybėmis pažinti šiuos žmones iš arčiau (Gudonis, Novogrodskienè, 2000: 51). Ne vienas informantas, patyręs stuburo trauma, atviravo, jog anksčiau savo gyvenime neigalių žmonių 
nebuvo sutikęs, todèl visiškai nežinojo, kaip orientuotis naujoje situacijoje ir kad iš viso įmanoma gyventi visaverti gyvenimą sẻdint neigaliojo vežimèlyje:

Aš anksčiau nematydavau neigaliuju, praeidavau, ir viskas. (Rūta, 39 m., su negalia $19 \mathrm{~m}$.)

Kai sveikas buvau, tai aš žmoniu vežimèliuose, atvirai pasakius, net nemačiau. (Valius, 37 m., su negalia $9 \mathrm{~m}$.)

Dèl šios pažinimo stokos visuomenėje vyrauja klaidinga vežimèlyje sèdinčio žmogaus tipizacija, suplakant skirtingas negalios formas ị vieną kategoriją bei priskiriant ji žemiausiai ekonominei, socialinei klasei, o tai reiškia, kad egzistuoja supratimo tarp igaliųjų ir neigaliujuc problema. Iš Mariaus Daugėlos (2006) kokybinio tyrimo apie fiziškai neigalaus žmogaus socialinị vaizdini rezultatų matyti, jog vežimėlyje sėdinčiam neigaliam asmeniui neretai priskiriamos papildomos ",negalios “, tokios kaip asocialumas, socialinè auka ar net proto negalia (p. 14). Šio tyrimo informantų refleksijos taip pat patvirtina minimų socialinių nuostatų egzistavimą. Informantas Tomas išsako nuoskaudą dèl tokios išankstinès „sveikujųu“ nuostatos jo atžvilgiu:

T.: O kuo pasireiškia tas visuomenès požiūris?

T.: Kad tave taip anksti nurašo. Net nepabendravęs su tavim, net nepažista, kas tu toks išvis esi, i tave žiūri baugiai, lyg i protiškai atsilikusi žmogu. Jeigu pamatai žmogu, sédintị vežimèlyje, kuris yra normalios büsenos, tu prieik, pabendrauk, tada susidaryk nuomone, ar jis blogesnis už ta sveika. (Tomas, $42 \mathrm{~m}$. , su negalia $19 \mathrm{~m}$.)

Panašia nuoskauda dalijasi Virginija, iš kurios pasakojimo taip pat matyti, kad praeiviai gatvejje vis dar dažnokai neigalujij suvokia kaip nevisavertị ir nelygiavertị jiems subjekta, kurị jam girdint galima aptarinèti kaip infantilų ar ribotų intelekto gabumų subjektą:

Viena karta tai jau viršūnè buvo. Važiuojam su sese, mama stumia vežimèli, ir du vyrai stovi, kalbasi, vienas atsisuko: „Žiūrèk, žiūrèk, vargšé važiuoja!" Apsimetu, kad negirdžiu, bet galvoju, kad tu pats vargšas, tai jau visai kaip koks debiliukas, čia nekultūringa baisiai. (Laura, 45 m., su negalia $19 \mathrm{~m}$.)

Tyrimo dalyvės Modestos papasakotas nutikimas ir refleksijos atskleidžia kitą dažną "sveikųjų“ stereotipą apie neigalų asmenį kaip 
nelaiminga, likimo nuskriaustą, įkūnijanti negalios kaip asmeninès tragedijos sampratą:

Čia, stovykloje, gyveno viena šeima su vaikais, jie sveiki, tik vyras po ligos. Tai vaikai mamai sako: "Šitos ne invalidès - jos linksmos." Kaip įdomiai vaikas pasake. Ir ka tai rodo? Rodo, kad sveikuju yra standartas: invalidas turi büti paniuręs, susiraukęs, dar ašara kokia rieda - tai jau čia bus standartas sédinčio vežimélyje. (Modesta, $41 \mathrm{~m}$., su negalia $23 \mathrm{~m}$.)

Respondentès vaizdingai nupieštas stereotipas atsikartoja M. Daugèlos (2006: 14) tyrimo išvadose apie egzistuojanti visuomenès požiūrị i neigalų asmenị kaip ị vargša, socialiai nuskriaustajji, kurị reikia šelpti ir kuris turètų būti dèkingas už parodytą praeivių „dosnumą“. Vežimèliu judantys respondentai ypač dažnai išreiškia nepasitenkinimą tokiu stereotipizavimu. Toks „,sveikujuč elgesys demonstruoja dideli adekvačiu žinių ir suvokimo apie judejjimo negalią turinčiuosius trūkuma, kuris neretai tampa tarp jų atsirandančių komunikacinių nesklandumų priežastimi. Pavyzdžiui, lūkuriavimas sẻdint vežimėlyje viešoje vietoje visai nereiškia neigaliojo motyvo prašyti išmaldos, laukti užuojautos ar tikètis panašaus elgesio iš aplinkinių, kaip ji interpretuoja dažnas praeivis:

Kažkada sustojau prie parduotuvés, draugai nuejo i parduotuvę, o aš laiptais neìvažiuoju; žiūriu, eina žmonés pinigu padèt, galvoja, ubagas išmaldos prašo. Tokiu variantu dažnai būna. (Algis, $35 \mathrm{~m}$., su negalia $9 \mathrm{~m}$.)

Šis respondento pasakojimas iliustruoja tarp igalių ir neigalių visuomenès narių tarpusavio sąveikos metu egzistuojančią intersubjektyvaus supratimo stoka, kuri pasireiškia sąveikaujančių veikèjų elgesio motyvų nesupratimu. A. Schützo teigimu, gyvenamajame pasaulyje veikiančių subjektu abipusis suvokimas visada yra motyvacinis, t. y. suvokiant, o greičiau nuspèjant vienas kito veiksmo motyvus. Reiškini, kai socialiniai veikèjai tikisi vienas iš kito tam tikro veiksmo, A. Schützas vadina „motyvų abipusiškumu“ (reciprocity of motives). Jeigu vienas veikejjas supranta kito veikejjo veiksmo intenciją ir i ją atsako, tai šioje tarpusavio sąveikoje veiksmo iniciatoriaus ",tam, kad“ motyvas tampa kito veikèjo "dèl to" motyvu (Schutz, 1970: 180). Šią motyvų abipusiškumo tezę A. Schützas papildo kita - perspektyvų abipusiškumo (reciprocity of perspectives) teze, teigdamas, jog vienoje dviejų subjektų bendros komunikacinès erdvės situacijoje, t. y. esant tiesioginejje vienas kito patirtyje, esti dvi subjektyvios perspektyvos (Wagner, 1970: 33), tačiau kiekvienas iš komunikuojančių asmenų siekia intencionaliai perkelti save i kito asmens vietą ir tarsi kitą patirti bei suvokti iš jo situacijos perspektyvos. 
Būtent iš tyrimo metu surinktų informantų pasakojimų matyti, kad šio perspektyvų ir motyvų abipusiškumo pasigendama tarp negalią turinčių ir neturinčių žmonių, kai jie atsiduria bendroje komunikacinejje erdvejje.

Viena vertus, iš aukščiau minèto „Vilmorus“ tyrimo pateiktų duomenu matyti, jog negalios neturintys respondentai bendrauja su turinčiais judejjimo negalią kaip su bet kuriais kitais žmonėmis $-87,7$ proc., nes jie, palyginti su kitas negalias turinčiais žmonėmis, mažiausiai sukelia neigiamų emocijų, ir tik 1,5 proc. respondentų nurodè, kad su jais nesinori bendrauti. Nors A. Dobryninas ir V. Gaidys (2003) yra tos nuomonès, kad net jei respondentai kiek ir "pagražino" savo atsakymus, vis vien tokie rezultatai kalba apie padidejusi visuomenès tolerancijos neigaliesiems lygi (p. 13). Nagrinèjamo tyrimo duomenys taip pat rodo panašias tendencijas, nes be išimties visi vyresnès kartos judejjimo negalią turintys respondentai iš tiesų pastebi, kad tolerancijos lygis nūdienos visuomenèje yra ženkliai išaugęs, palyginti su sovietmečiu, kai socialinė neigaliụjų izoliacija buvo totali:

[Neigalus yra] toks pat žmogus, džiaugiamès, džiaugiamés, kad visuomene neignoruoja... Daugiau esi matomas, priimtinas, ir tokiu pačiu žmogum aš jaučiuosi. (Rimantas, 47 m., su negalia $28 \mathrm{~m}$.)

O psichologiniu požiūriu dabar kažkaip geriau. Dabar kiti laikai. Anksčiau tai tokiu su vežimèliais retai kur pamatydavai, visi buvo užsidarę namuose, mažai kas mus matè, o dabar kažkokio tai diskomforto nejaučiu. (Mindaugas, $44 \mathrm{~m}$., su negalia $38 \mathrm{~m}$.)

Kita vertus, minèto sociologinio tyrimo išvadose pateikiama prielaida, jog aukščiau pateikti tyrimo rezultatai daugiau rodo žmonių intencijas, kurios gali būti geresnès nei atsiskleidžianti reali igaliųjų bendravimo su negalią turinčiaisiais padètis (Dobryninas ir Gaidys 2003: 16). Tad intersubjektyvaus supratimo tarp šių visuomenès grupių problema, kaip rodo pristatomo disertacinio tyrimo duomenys (Viluckienė, 2011), išlieka iki šių dienų.

Dar viena socialinių sąveikų, kurių metu fiziškai neigalūs asmenys patiria intersubjektyvios komunikacijos trūkumą, pasireiškianti supratimo, geranoriškumo, atidumo, îsiklausymo stoka, rūšis yra santykiai su socialiniais darbuotojais, savivaldybių socialinių reikalų skyrių darbuotojais ir specialistais, taip pat ir sveikatos priežiūros specialistais. Paradoksalu tai, kad šiose srityse dirbantys žmonès iš visų kitų visuomenės narių kaip tik turètų geriausiai pažinti judèjimo negalią turinčių asmenų gyvenimo tikrovę, jos specifiką ir, iškilus sunkumams ar neaiškumams, 
suteikti efektyvią bei kompetentingą pagalba, tuo tarpu jie pačių neigaliụjų apibūdinami kaip visų šių savybių neturintys. Nemažai kalbintų informantu socialinius darbuotojus, su kuriais jiems teko susidurti, kaltina visiška nekompetencija ir savo darbo neišmanymu:

Kad iš tu darbuotoju [socialiniu] maža nauda, mes daugiau žinom už juos, nes jie neturi didelès patirties. (Mindaugas, $44 \mathrm{~m}$. ., su negalia $38 \mathrm{~m}$.)

$\mathrm{Na}$, tai yra visiškai nekvalifikuoti, nepatyrę žmonès, supranti. (Petras, $37 \mathrm{~m}$., su negalia $37 \mathrm{~m}$.)

Bèda ta, kad neigaliuju organizacijose dirba žmonès, mažai žinantys apie pačia negalia. Reikia tokiam darbui paruošti žmogu, sudaryt programas. <...> Ateina žmonès paprasčiausiai neparuošti tam darbui. Kodèl? Todèl, kad jie labai mažai turi praktinio bendravimo su tais žmonèmis, kuriems reikalinga socialiné pagalba. (Marija, $50 \mathrm{~m} .$, su negalia $50 \mathrm{~m}$.)

Informantai taip pat skundžiasi, kad, kreipdamiesi i socialinių reikalų skyriuose dirbančius specialistus, kuruojančius atitinkamą socialinę sritị, negauna iš jų kvalifikuotos informacijos, susijusios su įstatymais, nuostatais ar potvarkiais, reglamentuojančiais jų kaip neigalių visuomenès narių socialines teises. Jie priversti patys išsiaiškinti, ką daryti atsiradus naujai situacijai, kadangi turimų žinių nebepakanka. Negaudami jų iš minètų specialistų, informacijos jie bando ieškoti interneto duomenų bazėse ar per pažistamų, turinčių judejjimo negalia, neformalų socialinị tinklą:

Bet nèra didelio susidomèjimo, išaiškinimo, kas priklauso sédinčiajam vežimélyje, turi pats susižinoti. (Mindaugas, $44 \mathrm{~m}$., su negalia $38 \mathrm{~m}$.)

Pavyzdžiui, kai prikepa va tu socialiniu [darbuotoju] tiktais kad prikeptu, tai čia nieko gero, nes, pavyzdžiui, nei pasiteirauti negali ju, kai žmogui kažko reikia ar kažkam pagalbos. (Justas, 34 m., su negalia 18 m.)

Be to, dauguma apklaustų informantų vengia kontaktų su socialiniais darbuotojais ar socialinių reikalų skyrių specialistais, nes ne kartą yra patyrę jų atsainuma, šaltuma, grubuma, kitomis panašiomis negatyviomis emocijomis persmelktą ju požiūrį. Todèl iškylančius reikalus su jais tvarkyti dažnai paveda savo artimiesiems. Darius, Violeta ir Donata šitaip atsiliepia apie bendravimo su socialinès srities specialistais patirtį:

$\mathrm{Na}$, socialinès rūpybos skyriuose aš stengiuos su jais reikalu neturèt daug, nes jie kažkaip nelabai mandagūs, nelabai malonūs. Dokumentus pristatau, ir viskas. Tuo ir pasibaigia mano bendravimas. (Darius, 24 m., su negalia $24 \mathrm{~m}$.) 
Bendravimas šiurkštus, man nepatinka. Galbūt daugiausia iš to nepatogumo sédèjime vežime tai va bütent tas susidūrimas su jais, todèl aš stengiuos nesusidurti. (Violeta, $36 \mathrm{~m}$. , su negalia $17 \mathrm{~m}$.)

Nepatinka man su jais kontaktuoti, nes iš ju niekada nieko gero nesulauki. (Donata, $27 \mathrm{~m}$. , su negalia $8 \mathrm{~m}$.)

Patys neigalieji suvokia, kad problemos, kylančios socialinių sąveikų su minètais specialistais metu, atsiranda dèl to, kad specialistams stinga ju tiek teorinio, tiek praktinio žinojimo ir patirčių atsargos. O igyti ją esant tokiai dabartinei socialinių paslaugų sistemai, informantų nuomone, yra mažai tikètina. Labiausiai jie galètų pasitikèti tais socialiniais darbuotojais, kurie patys ar jų šeimos nariai yra patyrę negalią:

Tose organizacijose turètu dirbti žmonés, kurie atspindètu ta negalia. <..>> Jeigu jis turès nors maža negalia, tai jis labiau supras, atjaus, stengsis padéti. (Marija, $50 \mathrm{~m}$., su negalia $50 \mathrm{~m}$.)

Pirmiausia, ko gero, reikia keisti socialiniu paslaugu visa struktūrą. Esu labai nepatenkinta, vienas, ir stengiuosi nesinaudoti, <...> per visus tuos metus pirma karta paprašiau, kad man padarytu pritaikyma, tiesiog patobulintu ivažiavima i nama. <...> Ir susidūriau su labai tokiu požiūriu: „Kam tau reikia?" Tai va, labai siutina darbuotoju socialiniu toks nesupratimas arba nenorejjimas daryti. (Violeta, $36 \mathrm{~m}$., su negalia $17 \mathrm{~m}$.)

Judèjimo negalią turintys asmenys neišvengiamai susiduria su sveikatos problemomis, dèl kurių jiems tenka kreiptis ị sveikatos priežiūros specialistus. Kontaktuodami su jais labai dažnai jie patiria stigmatizuojantị santyki, kuris paremtas medikų biomedicininiu ir funkcionalistiniu požiūriu ị neigalų asmeni kaip i̇ permanentinị ligoní, kuris negali imtis visuomenei naudingų socialinių vaidmenų, todèl yra vertinamas kaip „antrarūšis" pacientas, ì kuri neverta investuoti deramo dèmesio ir jèguc. Tačiau svarbu patikslinti, kad informantai neigiamai atsiliepia ne apie gydytojus, padejusius atsigauti po, pavyzdžiui, patirtos stuburo traumos, bet daugiausia apie pirminės sveikatos priežiūros specialistus, i kuriuos retsykiais tenka kreiptis. Informanto Petro išsakytas požiūris atitinka daugelio kitų informantų nuomonę:

Manau, yra koks ne daugiau kaip dešimt procentu mediku, kurie tikrai normaliai, nuoširdžiai žiüri i tave kaip ì žmogu, supranti. O visi kiti [nori] atsikratyti, atstumti, nežinau; arba išvis ten, žinai, labai, labai šaltai su tavim [elgiasi]. (Petras, $37 \mathrm{~m}$. , su negalia $37 \mathrm{~m}$.) 
Toks medikų požiūris i judejjimo negalią turinčius asmenis pasireiškia ju atsainumu ir nenoru gilintis i besikreipiančių neigaliųjų sveikatos problemas, kurios nebūtinai kyla dèl neigalaus kūno funkcionavimo sutrikimų. Romos ir Tomo pasakojimai labai gerai parodo dažnai sutinkamas ką tik aptartas medikų nuostatas neigaliujų atžvilgiu:

[Bendravimas] su tais medikais, su kuriais susidūriau, man paliko nekoki ispūdi, turiu omeny pirmaja šeimos gydytoja: "Ka, jinai dar dirba turédama pirma grupę?" Tai gaunasi toks požiūris: turi sèdèti namie ir nekišti niekur nosies su tokia negalia. Jeigu jau mediko toks požiūris, tai koks tada eilinio žmogaus? (Roma, 40 m., su negalia $8 \mathrm{~m}$.)

Kad ir paprasčiausias koks nors negalavimas, pavyzdžiui, sutrauke piršta, tu nueini pas gydytoja, tai jis: „Ko tu nori, juk tu vežimély sédi!“ Nesvarbu, kad aš dar jaunas. <...> Iš karto tau nustato ligos diagnozę: visos ligos nuo sédéjimo vežimélyje. (Tomas, $42 \mathrm{~m}$., su negalia $8 \mathrm{~m}$.)

Šio skyriaus informantų naracijų analizè leidžia konstatuoti, jog socialiai sąveikaujant judejjimo negalią turintiems ir jos neturintiems visuomenès nariams neretai pasireiškia intersubjektyvaus (abipusio motyvacinio) supratimo trūkumas. Jis kyla iš skirtingai suformuotų tipizacijų ir interpretacinių schemų, kuriomis vadovaujasi šių grupių nariai. Minètas supratimo trūkumas pasireiškia neprašomos išmaldos davimu neigaliojo vežimėlyje sẻdintiems žmonėms, atviro gailesčio rodymu ar jo išsakymu, ịkyriu žiūrèjimu ir panašiais jiems nepageidaujamais veiksmais. Tai rodo, kad visuomenè nėra susipažinusi su fiziškai neįgalių asmenų išgyvenama socialine tikrove. O socialiniai darbuotojai ir sveikatos priežiūros specialistai, remiantis tyrimo duomenų naratyvine analize, taip pat neturi pakankamo žinių bagažo apie judejjimo negalią turinčius žmones, besikreipiančius į juos sveikatos ir/ar socialinių problemų sprendimo, socialinių paslaugų užsakymo klausimais, kad galètų suteikti kompetentingą pagalbą, tenkinančią jų poreikius.

\section{IŠVADOS}

Kokybinio tyrimo metu surinktos ir išanalizuotos judejjimo negalią turinčių žmonių naracijos kaip reflektuota jų patirtis, išgyventa atsitiktinių ir institucionalizuotų socialinių sąveikų metu su igaliaisiais, atskleidžia, kad visuomenė nepažįsta šių asmenų gyvenimiškos tikrovės, nesuvokia jų problemų ir nežino, kaip adekvačiai sąveikauti, atsidūrus su jais kartu 
bendroje komunikacinejje erdvëje. Negalios neturinčių žmonių žinojimo bagaže apstu klaidingų stereotipų bei neigiamų išankstinių nuostatų neigaliujuc atžvilgiu, kurios sudaro palankias sąlygas igaliems visuomenės nariams primesti nelygiaverčius santykius: socialinių sąveikų metu neigaliuosius stigmatizuoti ir priskirti žemesniam socialiniam statusui. Toks neadekvatus šių asmenu pažinimas ir jų supratimas palaiko vis dar egzistuojančią visuomenėje socialinę i̇tampą tarp negalią turinčių ir neturinčių žmonių. Šią įtampa ypač pasireiškiančią socialinių sąveikų metu, būtų galima šiek tiek sumažinti, jeigu visuomenè būtų labiau informuota ir artimiau supažindinta su vežimèliais judančių asmenų gyvenamuoju pasauliu.

Gauti tyrimo rezultatai atskleidžia, kad socialinès bei sveikatos priežiūros specialistai bendraudami su neigaliaisiais taip pat parodo savo socialinę galią. Pirminès sveikatos priežiūros įstaigose dažniausiai neigalieji priskiriami , antrarūšiams" pacientams, kurie stokoja deramo specialistų dėmesio. Šios neigalių žmonių reflektuotos patirtys rodo tebeegzistuojančią medicinos specialistų tendenciją vadovautis biomedicininiu ir funkcionalistiniu požiūriu į neiggalų asmenị kaip į nepagydomą ligonį ir nenaudingą visuomenès narị. Nors neigaliesiems socialines paslaugas teikiantys darbuotojai ar juos kuruojantys specialistai turètų gerai išmanyti žmonių su judejjimo negalia gyvenimo specifiką bei teikti jiems kompetentinga pagalba, daugeliu atveju patys neigalieji tvirtina, kad šie specialistai tokių savybių neturi, o socialinės sąveikos pobūdis su jais - nepriimtinas.

Tad socialiniai darbuotojai, rengiami teikti socialines paslaugas ar kitais būdais dirbti su judejjimo negalią turinčiais asmenimis, pirmiausia turètų būti žymiai geriau ir išsamiau supažindinami su intersubjektyviai išgyvenama judejjimo negalios tikrove ir tǔ žmonių patirtimi, t. y. iggti igūdžių pažvelgti i judejjimo negalią turinčiujjų problemines situacijas, ị jų pagalbos prašymus iš sėdinčiųjų neigaliojo vežimèlyje perspektyvos, kuri ženkliai skiriasi nuo vaikštančio, negalios neturinčio žmogaus suvokimo perspektyvos. Pagilintos žinios padètų kurti tvirtesnius abipusio supratimo tiltus tarp negalią turinčių ir neturinčių visuomenės narių ivvairių socialinių sąveikų metu, taip pat teikiant vienos ar kitos rūšies socialinę pagalbą ar paslaugas. 


\section{LITERATŪRA}

1. Daugèla, M. (2006). Fiziškai neiggalaus žmogaus socialinis vaizdinys ir jo struktūra: kokybinio tyrimo rezultatai. Specialusis ugdymas, 1 (14): 8-18.

2. Dobryninas, A., Gaidys, V. (2003). Neigaliuju padeties Lietuvoje vertinimas. Vilnius: Visuomenės nuomonès ir rinkos tyrimu centras "Vilmorus".

3. Gudonis, V., Novogrodskienė, E. (2000). Visuomenès požiūris į neiggaliuosius suaugusius ir specialiuju poreikiu vaikus. Specialusis ugdymas. Mokslo darbai III: 50-62.

4. Gurwitsch, A. (1975). Introduction, in. Schutz, A. Collected Papers III: Studies Phenomenological Philosophy. Ed. I. Schutz. The Hague: Martinus Nijhoff.

5. Natanson, M. (1970). Alfred Schutz on Social Reality and Social Science. Phenomenology and Social Reality: Essays in Memory of Alfred Schutz. Ed. M. Natanson. The Hague: Martinus Nijhoff.

6. Parsons, T. (1951). The social system. New York: Free Press.

7. Schutz, A. (1967). The Phenomenology of the Social World. New York: Northwestern University Press.

8. Schutz, A. (1970). On Phenomenology and Social Relation. Ed. R. H. Wagner. Chicago and London: The University of Chicago Press.

9. Šeporaitytė, D., Tereškinas, A. (2007). Neigaliuju ịsidarbinimo ir mokslo galimybes Lietuvoje: tyrimo ataskaita. VDU.

10. Šulteisas, J. (1975). Akluju integracija istoriniu ir sisteminiu požiūriu. Vilnius: LAD leidykla.

11. Viluckienè, J. (2011). Judëjimo negalia turinčiu asmenu fenomenologinè gyvenamojo pasaulio analize (daktaro disertacija,Vilniaus universitetas).

12. Wagner, H. (1970). Introduction: The Phenomenological approach to Sociology. Schutz, Alfred. On Phenomenology and Social Relation. Ed. R. H. Wagner. Chicago and London: The University of Chicago Press.

\section{SUMMARY}

\section{SOCIAL INTERACTION BETWEEN THE MEMBERS OF A SOCIETY WITH OR WITHOUT A MOTOR DISABILITY: SOCIOLOGICAL PHENOMENOLOGICAL PERSPECTIVE}

The article applies Alfred Schutz's sociological phenomenological perspective to explore how people in wheelchairs experience and interpretsocial interactions with non disabled people.Their personal 
narratives are based on the qualitative in-depth interviews. Sociological phenomenological analysis of these narratives disclose the a lack of intersubjective (mutual motivational) understanding which exists in social interactions of people with motor disability and other members of society. It arises from differently formed typifications and interpretational schemes, which are followed by members of these groups. The mentioned lack of understanding evidences by unrequested charity of passers-by for people sitting in a wheelchair, open display of compassion or its expression, bored staring at them and similar actions, which are undesirable by disabled. This shows that society is still not familiar with the social reality, lived by disabled persons. Due to this unfamiliarity during social interactions the disabled members of society are imposed with unequal relationships: they are stigmatized and classified as having a lower social status.

Social and health care professionals also show their social power in relationship with disabled ones. In the primary health care institutions they are generally classified as "second-class" patients, who lack proper attention from professionals. These experiences, reflected by disabled people, show the existing trend of medical professionals to follow the biomedical and functionalist view towards a disabled person as towards an incurable patient and useless member of society. Although employees, providing social services for people with disability, or supervising professionals should be well aware of living specificity of people with motor disability, should be able to provide a competent support, however, in many cases the disabled ones argue that these professionals do not have the aforementioned characteristics, and the nature of social interaction with them is unacceptable. 